\title{
HUBUNGAN INDEKS MASSA TUBUH (IMT), LINGKAR LEHER DAN LINGKAR PERUT DENGAN RESIKO TERJADINYA OBSTRUCTIVE SLEEP APNEA (OSA) PADA PASIEN CORONARY ARTERY DISEASE (CAD) DI RSUP Dr. HASAN SADIKIN BANDUNG
}

\author{
Ai Cahyati \\ Dosen Jurusan Keperawatan Poltekkes Kemenkes Tasikmalaya
}

\begin{abstract}
Obstructive Sleep Apnea (OSA) can give complicated burdens on Coronary Artery Disease (CAD). This research aimed at indentifying factors which relate to risks of the occurrence of OSA on patients with CAD. This research employed Cross Sectional Design. The total of respondents were 161 respondents. The measurement of OSA risks was conducted using questionnaires. The result of data analyse identified that there is a significant correlation among IMT, circle of neck and belly with the risks of OSA occurrence. Recommendation reveals that screening on the risks of OSA occurrence is needed for CAD patients.
\end{abstract}

Key words: Obstructive Sleep Apnea, Coronary Artery Disease

\section{PENDAHULUAN}

Semakin hari angka kematian akibat penyakit kardiovaskular semakin meningkat, bukan hayna menyerang usia lanjut tetapi juga menyerang usia muda. Pola hidup yang tidak sehat, tidak berolah raga, merokok, manajemen mempunyai kontribusi besar terhadap peningkatan kasus penyakit kardiovaskular. Di Amerika Serikat setiap harinya lebih dari 2200 orang Amerika meninggal karena penyakit kardiovaskular atau sekitar enam orang meninggal setiap 39 detik. Pada tahun 2008 rata-rata kematian karena penyakit kardiovaskular sekitar 244.8 per 100.000 (American Heart Association/AHA, 2012). Sebagian besar penyebab penyakit kardiovaskular adalah aterosklerosis pada arteri koroner (Copsted \& Banasik, 2005). Black dan Hawks (2009) menyatakan bahwa Coronary Artery Disease (CAD) merupakan penyakit kardiovaskular yang paling banyak ditemukan dan menjadi penyebab utama dari kematian karena penyakit jantung. Di Amerika Serikat pada tahun 2008 angka kematian akibat penyakit jantung koroner pada tahun 2008 mencapai 405.309 orang, dan pada tahun berikutnya diprediksi mengalami kenaikan yaitu sebanyak 785.000 orang akan mengalami serangan penyakit jantung koroner dan 470.000 orang akan mengalami kekambuhan.

$\mathrm{Di}$ Indonesia terjadi pergeseran penyebab kematian yaitu bergeser dari penyakit infeksi ke penyakit tidak infeksi. Berdasarkan hasil Riset Kesehatan Dasar (RISKESDAS) tahun 2007 menyebutkan jumlah kasus penyakit jantung iskemik menduduki urutan kedelapan dari 22 jenis kasus penyakit (Badan Litbangkes Depkes, 2007). Di Jawa Barat angka kematian penyakit jantung masih tinggi yaitu sekitar 4258 dari 14061 total morbiditas (30\%), paling banyak menyerang pasien usia 45 s.d. 64 tahun dan lebih dan penyakit jantung ini menjadi penyebab pertama kematian.

Salah satu gangguan yang dialami pasien yang mengalami gangguan kardiovaskular adalah gangguan tidur. The society of respiratory care Indonesia/ Respina (2006) menyatakan bahwa salah satu gangguan tidur pada pasien gangguan kardiovaskular adalah sindrom henti napas saat tidur /sleep apnea. Peranan tidur sangat penting karena tidur mempunyai 
fungsi untuk restorasi dan homeostasis seluruh sistem organ tubuh. Obstructive Sleep Apnea (OSA) merupakan salah satu jenis Sleep apne. Gejala pasien dengan OSA adalah tidur dengan mendengkur keras, tersedak saat tidur, melaporkan adanya henti napas saat tidur dan gerakan abnormal saat tidur serta nokturia. Sebagai efek kejadian tersebut, maka muncul keluhan-keluhan yang sering dirasakan pada siang hari yaitu berupa rasa kantuk terus menerus (hipersomnolen), gangguan konsentrasi, sakit kepala pagi hari, gangguan intelektual, gangguan personalitas, depresi dan penurunan libido (Sumardi, Hisjam, Ryanto \& Budiono, 2010).

Alat baku emas untuk mendiagnosa OSA adalah Polisomnografi, hasil yang dapat ditemukan pada orang yang mengalami OSA adalah henti nafas > 10 detik, tetapi usaha nafas tetap ada, jumlah frekuensi penurunan aliran udara yang berhubungan dengan kolapsnya saluran nafas atau Apnea-Hipopnea Index (AHI) lebih dari 5 kali dalam 1 jam tidur. Fenomena yang terjadi saat ini OSA belum mendapat perhatian serius dari praktisi kesehatan, padahal OSA telah dikenal secara klinik OSA sudah didiagnosa sejak lebih dari 30 tahun yang lalu, selain itu minimnya alat polisomnografi di fasilitas kesehatan menyebabkan OSA tidak terdiagnosa secara pasti sehingga menyebabkan angka insiden OSA tidak diketahui secara pasti, padahal OSA menjadi faktor resiko utama dan akhirnya menyebabkan pasien yang mengalami OSA tidak tertangani (Hill, 2012).

Berdasarkan hasil pemantauan Hill (2012) selama beberapa tahun dan menyimpulkan bahwa OSA merupakan faktor risiko untuk terjadinya CAD. OSA mengakibatkan terjadinya hipoksia kemudian menstimulus syaraf simpatik dan menyebabkan stres otot miokardium, dan pada akhirnya akan mempengaruhi perfusi miokardium. Hal ini meningkatkan risiko pasien CAD yang mengalami OSA untuk mengalami gagal jantung sebanyak 2,2 kali lipat (Hill, 2012).
Jumlah penderita OSA di Indonesia secara pasti belum diketahui. Insidensi OSA diperkirakan berkisar antara $2-4 \%$ pada orang menjelaskan bahwa terdapat beberapa faktor. Kelainan anatomi saluran nafas atas (hipertropi tonsil, palatum molle yang panjang), usia, jenis kelamin, obesitas (Body Mass Index > $28 \mathrm{~kg} / \mathrm{m} 2$ ), lingkar leher, hipertiroidisme, hiperlipid, hipertensi, genetik, alkohol, depresan susunan saraf pusat (hipnotik, opioid) menjadi faktor yang berkontribusi terhadap kejadian OSA (Respina, 2006 \& Lumbantobing, 2008).

Kegemukan merupakan resiko tinggi terjadinya OSA. Populasi dengan IMT yang lebih dari normal memiliki resiko lebih bersar terkena OSA, semakin tinggi IMT semakin tinggi seseorang terkena resiko OSA. Seseorang memiliki resiko 1,63 kali lipat terkena OSA pada orang yang memiliki IMT $25-30 \mathrm{~kg} / \mathrm{m} 2$, beresiko 5,38 kali lipat pada orang dengan IMT 30,1 - $40 \mathrm{~kg} / \mathrm{m} 2$, beresiko 7,11 kali lipat pada orang dengan IMT > $40 \mathrm{~kg} / \mathrm{m} 2$ (Harteunbaun, Collop \& Rose, 2006). Hal tersebut berhubungan dengan adanya deposit lemak di sekitar saluran pernafasan dan juga pelemasaan otot yang terjadi saat tidur dan akhirnya mengakibatkan penyempitan jalan nafas atas (Lumbantobing, 2008).

Lingkar leher juga menjadi salah satu faktor penyebab terjadinya OSA. Hasil penelitian Astuti, Yunus, Antariksa \& Ratnawati (2010) tentang prevalensi dan gejala klinis OSA pada pasien asma menjelaskan bahwa menyebutkan pasien dengan lingkar leher 33,6 tidak mempunyai risiko OSA sedangkan pasien dengan lingkar leher $37,9 \mathrm{~cm}$ mempunyai risiko OSA.

Walaupun untuk menegakkan diagnosa OSA itu masih terbatas karena tidak semua fasilitas pelayanan kesehatan di Indonesia memiliki alat Polisomnografi yang merupakan alat baku emas untuk menegakkan diagnose ASA, tetapi pemeriksaan terhadap resiko terjadinya OSA dapat dilakukan dengan mudah. Pemeriksaan resiko terjadinya OSA dapat dilakukan dengan memakai kuesioner. Saat 
ini kuesioner resiko OSA dikenal dengan kuesioner Berlin, kuesioner ARES. Kuestioner Berlin merupakan salah satu kuesioner yang baik yang dapat digunakan untuk screening OSA (Enciso \& Clark, 2011). Berdasarkan hasil penelitian Enciso \& Clark (2011) tentang studi perbandingan antara kuestioner Berlin dengan kuesioner ARES menyatakan kuesioner Berlin mempunyai sensitifitas lebih tinggi dibandingkan dengan ARES. Kuesioner Berlin sudah digunakan sebagai instrumen oleh The society of respiratory care Indonesi (Respina) untuk melakukan screening OSA di Indonesia.

Pada saat OSA terjadi, saluran nafas mengalami penyempitan, sehingga suplay oksigen ke paru-paru terhalang, tubuh mengalami hipoksemia intermiten, dan retensi $\mathrm{CO} 2$. Hal ini mengakibatkan terjadi stimulus syaraf simpatis, berupa vasokontriksi sistemik yang akan mengakibatkan hipertensi dan hipertensi. Tubuh mengalami penurunan saturasi oksigen hingga $60 \%$ dan akan mengakibatkan peningkatan afterload. Halhal tadi dapat menjadi penyebab inflamasi endotel yang akan meningkatkan resiko

\section{METODE PENELITIAN}

Rancangan penelitian ini adalah crossectional. Untuk mengukur IMT, lingkar leher dan lingkar perut peneliti melakukan penimbangan berat badan, pengukuran tinggi badan, pengukuran lingkar leher dan lingkar perut responden. Dan untuk mengukur resiko terjadinya OSA digunakan alat ukur berupa kuesioner screening resiko OSA yang dikeluarkan oleh Respina yang telah dimodifikasi. Kuesioner terdiri dari 2

\section{POPULASI DAN SAMPEL}

Populasi pada penelitian ini adalah semua pasien yang mengalami CAD. Jumlah sampel dalam penelitian ini adalah 161 responden. Yang menjadi kriteria inklusi penelitian ini adalah pasien yang didiagnosa $C A D$, diantar oleh keluarga yang tinggal serumah/pasangan dan bersedia
CAD. Bila terjadi pada pasien dengan gagal jantung maka peningkatan afterload tersebut mengakibatkan gagal jantung menjadi semakin berat. Selain itu, OSA juga mengakibatkan seseorang terbangun dari tidurnya secara tiba-tiba dan berulang dan hal tersebut mengakibatkan gangguan pada kualitas tidur pasien. Pasien mengalami hipersomnolen, merasa tidak segar saat bangun tidur dan penurunan konsentrasi (Febriani et al., 2011 \& Somer et al., 2008). Angka kejadian pasti OSA yang belum diketahui, besarnya akibat yang ditimbulkan oleh OSA terutama untuk pasien penyakit jantung, dan sepengetahuan peneliti penelitian tentang OSA membuat peneliti tertarik untuk mengadakan penelitian tentang hubungan Indeks Massa Tubuh (IMT), lingkar leher dan lingkar perut dengan resiko terjadinya Obstructive Sleep Apnea (OSA) pada pasien Coronary Artery Disease (CAD) di RSUP Dr. Hasan Sadikin Bandung. Tujuan dari penelitian ini adalah untuk mengetahui hubungan Indeks Massa Tubuh (IMT), lingkar leher dan lingkar perut dengan resiko terjadinya OSA pada pasien CAD di RSUP Dr. Hasan Sadikin Bandung.

macam, yaitu untuk pasien dan kuesioner untuk keluarga pasien yang sehari-hari tinggal dengan pasien untuk validasi terhadap jawaban dari kuesioner pasien. Hasil uji coba kuesioner terhadap 30 orang pasien menunjukkan baik kuesioner untuk pasien maupun untuk pasangan atau keluarga pasien menunjukkan kuesioner tersebut valid dan reliabel.

menjadi responden, sedangkan kriteria eksklusi dalam penelitian ini antara lain pasien tidak sadar dan pasien yang tidak didiagnosa psikosa. Penelitian ini dilaksanakan pada Bulan Oktober s.d. Desember 2012 di Ruang Poliklinik Jantung RSUP dr. Hasan Sadikin Bandung. 


\section{HASIL DAN PEMBAHASAN}

\section{Analisis Univariat}

Hasil analisis univariat menunjukkan bahwa sebagian besar responden memiliki IMT $\geq 25 \mathrm{~kg} / \mathrm{m} 2$ yaitu sebanyak 101 orang $(62,7 \%)$ dan sisanya 60 orang $(37,3 \%)$ memiliki IMT < $25 \mathrm{~kg} / \mathrm{m} 2$. Jumlah responden yang mempunyai lingkar leher $<40 \mathrm{~cm}$ lebih banyak dibandingkan dengan yang mempunyai lingkar leher $\geq 40 \mathrm{~cm}(63,9 \%$ : $16,1 \%) \quad(16,1 \%)$. Sebagian besar responden mempunyai lingkar perut $<80 \mathrm{~cm}$ $(68,3 \%)$ lebih banyak dibandingkan responden dengan lingkar perut $\geq 80 \mathrm{~cm}$ $(31,7 \%)$. Sebagian besar responden memiliki resiko tinggi untuk mengalami OSA yaitu 93 orang $(57,8 \%)$ dan sisanya memiliki resiko rendah sebanyak 68 orang $(42,2 \%)$. Hasil uji analisis univariat dapat dilihat pada tabel di bawah ini:

Tabel 1. Distribusi Responden Menurut IMT, Lingkar Leher, Lingkar Perut Di RSUP Dr. Hasan Sadikin Bandung Oktober-Desember 2012

\begin{tabular}{|c|c|c|}
\hline Variabel & $\begin{array}{l}\text { Jumlah } \\
(n=161)\end{array}$ & Persentase \\
\hline $\begin{array}{l}\text { I. IMT } \\
<25 \mathrm{~kg} / \mathrm{m}^{2} \\
\geq 25 \mathrm{~kg} / \mathrm{m}^{2}\end{array}$ & $\begin{array}{c}60 \\
101\end{array}$ & $\begin{array}{l}37,3 \\
62,7\end{array}$ \\
\hline $\begin{array}{l}\text { 2. Lingkar leher } \\
<40 \mathrm{~cm} \\
\geq 40 \mathrm{~cm}\end{array}$ & $\begin{array}{c}135 \\
26\end{array}$ & $\begin{array}{l}63,9 \\
16,1\end{array}$ \\
\hline $\begin{array}{l}\text { 3. Lingkar perut } \\
<80 \mathrm{~cm} \\
\geq 80 \mathrm{~cm}\end{array}$ & $\begin{array}{c}110 \\
51\end{array}$ & $\begin{array}{l}68,3 \\
31,7\end{array}$ \\
\hline $\begin{array}{l}\text { 4. Resiko terjadi OSA } \\
\text { Beresiko Rendah } \\
\text { Beresiko Tinggi }\end{array}$ & $\begin{array}{l}69 \\
93\end{array}$ & $\begin{array}{l}42,2 \\
57,8\end{array}$ \\
\hline
\end{tabular}

\section{Analisis Bivariat}

Hasil analisis hubungan antara IMT dengan risiko terjadinya OSA diperoleh bahwa jumlah responden dengan IMT $\geq 25$ $\mathrm{kg} / \mathrm{m}^{2}$ beresiko tinggi mengalami OSA lebih banyak yaitu sebanyak 83 orang (82,2 \%) dibandingkan dengan responden dengan IMT < $25 \mathrm{~kg} / \mathrm{m}^{2}$ yang berisiko tinggi mengalami OSA yang hanya ada 10 orang (16,7 \%). Hasil uji statistik menunjukkan ada hubungan antara IMT dengan risiko terjadinya OSA ( $p$ value $=0,001)$, dengan nilai $\mathrm{OR}=23,06$, artinya responden yang IMT $\geq 25 \mathrm{~kg} / \mathrm{m}^{2}$ mempunyai peluang 23,06 kali berisiko tinggi terjadinya OSA dibandingkan dengan yang IMT $<25 \mathrm{~kg} / \mathrm{m}^{2}$

Hasil analisis hubungan antara lingkar leher dengan risiko terjadinya OSA diperoleh bahwa jumlah responden dengan $\geq 40 \mathrm{~cm}$ beresiko tinggi untuk terjadinya
OSA lebih banyak yaitu sebanyak 23 orang (88,5 dibandingkan dengan responden yang lingkar leher $<40 \mathrm{~cm}$ yang berisiko tinggi mengalami OSA yang hanya ada 70 orang (51,9 \%). Hasil uji statistik menunjukkan hubungan antara lingkar leher dengan risiko terjadinya OSA ( $p$ value = $0,001)$. Responden dengan lingkar leher $\geq$ $40 \mathrm{~cm}$ mempunyai peluang 7,12 kali untuk terjadinya OSA dibandingkan dengan yang lingkar leher $<40 \mathrm{~cm}$ (nilai OR = 7,12).

Hasil analisis hubungan antara lingkar perut dengan risiko terjadinya OSA diperoleh bahwa ada sebanyak 48 orang $(94,1 \%)$ responden dengan lingkar perut $\geq$ $80 \mathrm{~cm}$ yang beresiko tinggi mengalami OSA dan hanya 45 orang $(40,9 \%)$ responden yang lingkar perut $<80 \mathrm{~cm}$ yang berisiko tinggi mengalami OSA. Hasil uji statistik 
menunjukkan ada hubungan antara lingkar perut dengan resiko terjadinya OSA ( $p$ value $=0,001)$. Hasil analisis menunjukkan nilai $\mathrm{OR}=23,11$ artinya responden dengan lingkar lingkar perut $\geq 80 \mathrm{~cm}$ mempunyai peluang 23,11 kali untuk terjadinya OSA dibandingkan dengan yang lingkar perut tidak berisiko $<80 \mathrm{~cm}$. Hasil uji bivariat dapat dilihat pada tabel 2 di bawah ini:

Tabel 2. Hubungan Variabel Independen dengan Risiko Terjadinya OSA

Bulan Oktober - Desember 2012

\begin{tabular}{|c|c|c|c|c|c|c|c|}
\hline \multirow[b]{2}{*}{ No } & \multirow[b]{2}{*}{ Variabel } & \multicolumn{2}{|c|}{ Risiko OSA } & \multirow{2}{*}{$\begin{array}{c}\text { TOTAL } \\
\text { N (\%) }\end{array}$} & \multirow[b]{2}{*}{$\mathbf{x}$} & \multirow[b]{2}{*}{ p Value } & \multirow[b]{2}{*}{ OR $(95 \% \mathrm{Cl})$} \\
\hline & & $\begin{array}{c}\text { Rendah } \\
\text { F (\%) }\end{array}$ & $\begin{array}{l}\text { Tinggi } \\
\mathbf{F}(\%)\end{array}$ & & & & \\
\hline \multirow[t]{3}{*}{1.} & IMT & & & & 63,56 & 0,001 & 1 \\
\hline & $<25 \mathrm{~kg} / \mathrm{m}^{2}$ & $50(83,3)$ & $10(16,7)$ & $60(100)$ & & & 23,06 \\
\hline & $\geq 25 \mathrm{~kg} / \mathrm{m}^{2}$ & $18(17,8)$ & $83(82,2)$ & 101(100) & & & $(9,87 ; 53,88)$ \\
\hline \multirow[t]{3}{*}{2.} & Lingkar leher & & & & 10,52 & 0,001 & 1 \\
\hline & $<40 \mathrm{~cm}$ & $65(48,1)$ & $70(51,9)$ & $135(100)$ & & & 7,12 \\
\hline & $\geq 40 \mathrm{~cm}$ & $3(11,5)$ & $23(88,5)$ & $26(100)$ & & & $(2,04 ; 24,84)$ \\
\hline \multirow[t]{3}{*}{3.} & Lingkar perut & & & & 38,28 & 0,001 & 1 \\
\hline & $<80 \mathrm{~cm}$ & $65(59,1)$ & $45(40,9)$ & $110(100)$ & & & 23,11 \\
\hline & $\geq 80 \mathrm{~cm}$ & $3(5,9)$ & $48(94,1)$ & $51(100)$ & & & $(6,78 ; 78,81)$ \\
\hline
\end{tabular}

\section{PEMBAHASAN}

\section{Hubungan Antara IMT Dengan Risiko Terjadinya OSA}

Pada penelitian ini lebih banyak responden dengan IMT $\geq 25 \mathrm{~kg} / \mathrm{m}^{2}$ yang beresiko tinggi untuk terjadinya OSA $(82,2$ $\%$ ) dibandingkan dengan responden yang IMT $<25 \mathrm{~kg} / \mathrm{m}^{2}$, dan hasil uji statistik mendukung hipotesis bahwa ada hubungan antara IMT dengan risiko terjadinya OSA.

$\mathrm{Hal}$ ini sesuai dengan penelitian yang dilakukan oleh Harteunbaun, Collop, Rosen (2006) bahwa kegemukan merupakan resiko tinggi terjadinya OSA paling tinggi. Populasi dengan IMT 25 - $30 \mathrm{~kg} / \mathrm{m} 2$ memiliki nilai risiko 1,63 kali lebih tinggi jika dibandingkan populasi normal, IMT 30,1 - $40 \mathrm{~kg} / \mathrm{m} 2$ memiliki resiko 5,38 kali dan populasi dengan IMT > $40 \mathrm{~kg} / \mathrm{m} 2$ memiliki risiko 7,11 kali lebih tinggi jika dibandingkan dengan populasi normal.

Hasil penelitian ini sesuai juga dengan hasil penelitian yang dilakukan oleh Matthew dan Brass (2011) bahwa berdasarkan studi epidemiologi secara konsisten menunjukkan bahwa berat badan khususnya BMI merupakan faktor risiko terkuat dari risiko terjadinya OSA. Responden yang obesitas dan mengalami
OSA yaitu sebanyak $26 \%$ pada pasien dengan IMT > $30 \mathrm{~kg} / \mathrm{m}^{2}$ dan $33 \%$ pada pasien dengan IMT $>40$. Penelitian yang dilakukan oleh Young, Peppard dan Gottlieb (2002) yang memperkirakan bahwa 1 dari 5 dewasa usia menengah dengan IMT 25-28 $\mathrm{kg} / \mathrm{m} 2$ menderita OSA, dimana 1 dari 20nya adalah asimptomatik. Kelainan ini juga terdapat lebih dari $40 \%$ pada mereka yang mempunyai IMT di atas $30 \mathrm{~kg} / \mathrm{m}^{2}$ dan umumnya pada individu dengan IMT 40 $\mathrm{kg} / \mathrm{m}^{2}$.

Proses obesitas menyebabkan OSA belum diketahui secara jelas, namun deposit lemak dan otot yang melemah dapat mengakibatkan penyempitan jalan nafas atas (Lumbantobing, 2008). Pada pasien yang IMT $\geq 25 \mathrm{~kg} / \mathrm{m}^{2} \quad$ mengalami penumpukan lemak di daerah sekitar leher, sehingga dapat mengubah volume saluran nafas menjadi lebih sempit. Perubahan tersebut akan mengakibatkan perubahan bentuk anatomi, lidah dapat terangkat sehingga mengurangi volume saluran nafas bagian atas. Selain itu juga pada saat tidur terjadi pelemasan otot pernafasan yang lajim terjadi pada semua orang saat tidur, tetapi bedanya pada orang mengalami OSA 
lidah tersebut jatuh ke belakang hamper menutup seluruh salauran pernafasan sehingga menghalangi suplay oksigen ke paru-paru (Cahyono, 2010 \& Lumbantobing, 2008). Hal ini yang mengakibatkan pasien cenderung merasa terhimpit saat tidur, ingin segera bangun, bangun dengan terengahengah dan itu terjadi berulang kali sepanjang siklus tidurnya. Hal tersebut akan mengaktifkan sistem syaraf simpatis berupa vasokontriksi sistemik yang akan mengakibatkan hipertensi. Tubuh mengalami penurunan saturasi oksigen hingga $60 \%$ dan akan mengakibatkan peningkatan afterload. Hal-hal tadi dapat menjadi penyebab inflamasi endotel yang akan meningkatkan kompleksitas penyakit pada pasien CAD. Selain itu juga OSA yang dialami pasien, akan mengakibatkan gangguan tidur sementara tidur tersebut berfungsi untuk memperbaiki fungsi-fungsi sel yang mengalami kerusakan. Carter \&

\section{Hubungan Antara Lingkar Leher Dengan Risiko Terjadinya OSA}

Hasil uji statistik mendukung hipotesis yaitu ada hubungan antara lingkar leher dengan risiko terjadinya OSA. Hal ini sesuai dengan hasil penelitian Gede et al., (2008) meneliti lingkar leher sebagai salah satu variabel independen dalam penelitian tentang prevalensi kemungkinan OSA dan faktor-faktor yang berhubungan pada pengemudi Taksi X di Jakarta. Gede et al., (2008) membagi lingkar leher menjadi 2 kategori yaitu $<40 \mathrm{~cm}, \geq 40 \mathrm{~cm}$. Hasil penelitian menunjukkan bahwa lingkar leher $\geq 40 \mathrm{~cm}$ memiliki risiko hampir delapan kali lipat untuk mengalami kemungkinan OSA. Pinto, Godoy, Marquis, Sonego \& Leal, et al., (2011) mengutip pendapat Dixon et al., (2003) yang menyatakan bahwa lingkar leher merupakan prediktif terbaik dari faktor resiko terjadinya AHI. Hal ini juga dikemukakan oleh Lumbantobing bahwa salah satu faktor risiko mengalami OSA adalah bila lingkar leher $\geq 40 \mathrm{~cm}$.

Matthew dan Brass (2011) mengungkapkan bahwa lingkar leher yang luas sangat berhubungan erat dengan
Watenpaugh (2008) mengungkapkan bahwa obesitas secara konsisten menunjukkan sebagai salah satu faktor risiko OSA terbesar.

Obesitas adalah faktor risiko OSA yang terbesar yang reversibel. Penurunan berat badan dalam jangka pendek (1-2 tahun) mengarah ke lebih baik regulasi metabolisme pasien dengan OSA (Pilar \& Shehadeh, 2008). Beberapa penelitian menemukan bahwa sleep apnea sedang sampai parah dapat sepenuhnya dikoreksi dengan menurunkan berat badan berlebih. Penurunan berat badan dapat membuka tenggorakan dan memperbaiki gejala apnea tidur (Smith, Robinson \& Segal, 2012). Selain itu, obesitas mungkin terlibat dalam pengaturan fungsi chemoreflex melalui mediator neuro-hormonal seperti leptin, yang menurun ketika tidur pasien OSA menurunkan berat badan (Pilar \& Shehadeh, 2008).

peningkatan resiko OSA. Pada kenyataannya lingkar leher $\geq 15,7$ in $(40 \mathrm{~cm})$ mempunyai sentivitas dan spesifisitas yang lebih besar dibandingkan dengan IMT dalam memprediksi terjadinya OSA. Jaringan lunak saluran pernapasan bagian atas yang abnomal mempunyai peranan dalam patogenesis OSA pada orang yang obesitas. Lingkar leher menunjukkan hubungan yang lebih baik dibandingkan dengan BMI dengan keparahan OSA, hal ini berhubungan dengan penumpukan lemak di leher berhubungan dengan patogenesis OSA. Ukuran lingkar leher meningkat juga disebabkan karena adanya perpindahan cairan dari kaki ke leher yang meningkat pada waktu malam hari yang disebabkan karena posisi tidur yang telentang (Karimi, Koranyi, Franco, Peker, Eder \& Angelhed, 2010) dan lingkar leher meningkatkan risiko OSA karena terjadi deposit lemak pada anterolateral saluran napas yang menyebabkan lumen saluran napas menyempit (Astuti, Yunus, Antariksa, \& Ratnawati, 2010). 


\section{Hubungan Antara Lingkar Perut Dengan Risiko Terjadinya OSA}

Hasil uji statistik mendukung hipotesis yaitu ada hubungan antara lingkar perut dengan risiko terjadinya OSA. Hal ini sesuai dengan hasil penelitian Pinto et al., (2011) menemukan adanya hubungan antara lingkar leher dan lingkar perut terhadap AHI yang signifikan, dan di antara keduanya lingkar perut mempunyai hubungan yang lebih signifikan $(p<0.001)$. $\mathrm{Hal}$ ini berhubungan dengan obesitas sentral (central obesity) yang merupakan akumulasi lemak di perut yang mengakibatkan peningkatan ukuran perut dan daerah di sekitar pinggang. IDF (International Diabetes Federation) membagi lingkar perut orang Asia yang tidak normal bila lingkar perut $\geq 90 \mathrm{~cm}$ (pada laki-laki) dan $\mathrm{P} \geq 80 \mathrm{~cm}$. Lingkar perut yang melebihi normal berhubungan erat dengan obesitas sentral (Soedondo \& Gustaviani, 2009).

\section{SIMPULAN}

1. Responden lebih banyak yang memiliki IMT $\geq 25$ lebih banyak, mempunyai lingkar leher $<40 \mathrm{~cm}$, dan lingkar perut $<80 \mathrm{~cm}$.

2. Responden yang beresiko tinggi terjadi OSA lebih banyak dibandingkan

\section{REKOMENDASI}

Pada pasien dengan CAD harus dilakukan screening risiko mejadinya OSA dengan menggunakan kuesioner yang telah baku atau teruji, dan kuesioner tersebut tersedia di ruangan, sehingga bagi pasien yang mempunyai risiko tinggi dapat dilakukan pemberian pendidikan kesehatan serta bila diperlukan tindakan lebih lanjut

\section{DAFTAR PUSTAKA}

American Heart Association. (2012). Heart disease and stroke statistics 2012 update: a report from American Heart Associatioan. Circulation, 125, e2-e220

Antariksa, B. (2010). Patogenesis, diagnostik dan skrining OSA
Stadler, McEvoy, Sprecher, Thomson, Ryan, Thompson \& Catcheside (2009) mengadakan penelitian tentang penekanan abdomen meningkatkan kolapnya saluran pernapasan bagian atas pada pasien pria obesitas dengan OSA. Obesitas perut memiliki dampak negatif terhadap saluran napas bagian atas saat tidur. Dengan adanya obesitas perut maka akan mengurangi pergerakan diafragma pada saat tidur. Penelitian ini bertujuan untuk menguji pengaruh kompresi perut pada fungsi saluran pernafasan atas pada saat tidur pada pasien laki-laki obesitas yang mengalami OSA. Hasil penelitian menunjukkan bahwa 15 responden yang obesitas (indeks massa tubuh: $34,5 \pm 1,1$ $\mathrm{kg} / \mathrm{m} 2$ ) mengalami OSA (AHI:58,1 $\pm 6,8$ peristiwa/jam) dan paling banyak dialami responden berusia $50 \pm 2,6$ tahun. Tekanan abdominal akibat obesitas perut mempunyai hubungan yang sangat kut dengan OSA.

dengan responden yang berisiko rendah.

3. Ada hubungan yang signifikan IMT, lingkar leher dan lingkar perut dengan risiko terjadinya OSA.

seperti merujuk ke poliklinik tidur. Selain itu perlu dilakukan pengukuran lingkar perut, lingkar leher pada pasien CAD dan hasil pengukuran tersebut tercantum dalam lembar dokumentasi tambahan khusus di bagian catatan cardiologi pada rekam medik pasien.

(Obstructive Sleep Apnea). Jakarta: Balai Penerbit UI

Astuti, P., Yunus, F., Antariksa, B., \& Ratnawati. (2010). Prevalensi dan gejala klinis Obstructive Sleep Apnea 
(OSA) pada pasien asma. $J$ Indon Med

Asso. Volum: 61, nomor: 7, Juli 2011

Badan Penelitian dan Pengembangan Kesehatan (2008). Laporan nasional riskesda 2007, Badan Penelitian dan Pengembangan Kesehatan Departemen Kesehatan, Republik Indonesia.

http://www.litbang.depkes.go.id.

Black, J.M., \& Hawks, J.H. (2009). Medical Surgical Nursing: Clinical Management for Positive Outcomes. Eighth Edition. Volume 2. USA: Saunders Elsevier.

Cahyono, A., Hermani, B., Mangunkusumo, E., \& Perdana, R.S. (2010). Hubungan obstructive sleep apnea dengan penyakit sistem kardiovaskular. Jakarta: Fakultas kedokteran Universitas Indonesia.

Carter, C., \& Watenpaugh. L. (2008). Obesity and obstructive sleep apnea: Or is it OSA and obesity? Pathophysiology, 15, 71-77.

Copstead, L.C., \& Banasik, J.L. (2005). Pathophysiology. Third Edition. St. Louis: Elsevier Saunders.

Enciso, R., \& Clark, G.T. (2011). Comparing the berlin and the ARES questionnaire to identify patient with obstructive sleep apnea in a dental setting. Sleep Breath Journal, 15 (1), 83- 89. Doi: 10.1007/s11325-010-0328-5.

Febriani, D., Yunus, F., Antariksa, B., \& Andrianto, H. (2011). Relationship between obstructive sleep apnea and cardiovascular (review article). Jurnal Kardiologi Indonesia, Vol 32, No. 1, 45 $-52$.

Gede, P., Adrianto, Susanto, A.D., Amri, Z., \& Antariksa, B.. (2008). Prevalensi kemungkinan obstruksi sleep apnea dan faktor-faktor yang berhubungan pada pengemudi taksi $X$ di Jakarta.

Harteunbaun, N., Collop, N., \& Rosen, I.M. (2006). Sleep apnea and commercial motor vehicle. JOEM. 2006, $48-37$.

Hastono, S.P. (2007). Analisis data kesehatan. Depok: Fakultas Kesehatan Masyarakat Universitas Indonesia
Karimi, M., Koranyi, J., Franco, C., Peker, Y., Eder, D.N., \& Angelhed, J.E. (2010). Increased neck soft tissue mass and worsening of Obstructive sleep apnea after growth hormone treatment in men with abdominal obesity. Journal of Clinical Sleep medicine, vol 6 No. 3, 256-263.

Lumbantobing, S.M. (2008). Gangguan tidur. Jakarta: Balai Penerbit FKUI.

Matthew,L.H., \& Brass,S.D. (2011). Obstructive sleep apnea. Neurology International, vol 3, e15

Pillar, N., \& Shehadeh, S. (2008). Abdominal fat and sleep apnea: the chicken or the egg? Diabetes Care 31 (Suppl. 2) S303-S309.

Pinto, J.A., Godoy, L.B., Marquis, V.W., Sonego, T.B., \& Leal, C.F et al., (2011). Anthropometric data as predictors of obstructive sleep apnea severity. Brazhjan Journal of Otorhnolaryngology, 77 (4), 517-521.

Sastroasmoro, S \& Ismael, S. (2011). Dasar-dasar metodologi penelitian klinis. Edisi ke-4. Jakarta: Sagung Seto.

Sumardi, H., Ryanto, B.S., \& Budiono, E. (2010). Sleep apnea. dalam buku ajar IImu Penyakit Dalam. Edisi 5. Jakarta: Interna Publishing

Somers, V.K., White, D.P, Amin, R., Abraham, W.T., Costa. F., Culebras, A., Daniels, S., Floras, J.S, Hunt, C.E., \& Olson, L.J., (2008). Sleep Apnea and Cardiovascular Disease: An American Heart Association/American College of Cardiology Foundation Scientific Statement From the American Heart Association Council for High Blood Pressure Research Professional Education Committee, Council on Clinical Cardiology, Stroke Council, and Council on Cardiovascular Nursing In Collaboration With the National Heart, Lung, and Blood Institute National Center on Sleep Disorders Research (National Institutes of Health). Circulation, 118, 1080-1111

Sugiyono. (2010). Metode penelitian kuantitatif kualitatif. Bandung: Alfabeta. 
Stadler, D.L., McEvoy, R.D., Sprecher, K.E., Thomson, K.J., Ryan, M.K., Thompson, C.C., \& Catcheside, P.G. (2009). Abdominal Compression Increases Upper Airway Collapsibility During Sleep in Obese Male Obstructive Sleep Apnea Patients. Sleep, Vol 32, No.12.

The Society of Respiratory Care Indonesia (RESPINA). (2009). Sleep Study: Pedoman diagnosis dan penatalaksanaan Sleep Disorder Breathing. Jakarta: PT Resindo Medika

The Society of Respiratory Care Indonesia (RESPINA). 2012. Sesak napas. Jakarta: Balai Penerbit Fakultas Kedokteran Universitas Indonesia. 